\title{
REDD+ Crossroads Post Paris: Politics, Lessons and Interplays
}

\author{
Esteve Corbera $^{1, *}$ (1) and Heike Schroeder ${ }^{2}$ \\ 1 Institute of Environmental Science and Technology, Universitat Autònoma de Barcelona, \\ 08193 Bellaterra, Spain \\ 2 School of International Development, University of East Anglia, Norwich NR4 7TJ, UK; \\ h.schroeder@uea.ac.uk \\ * Correspondence: esteve.corbera@uab.cat
}

Received: 18 December 2017; Accepted: 19 December 2017; Published: 20 December 2017

\begin{abstract}
This article introduces the special issue "REDD+ crossroads post Paris: politics, lessons and interplays". The contributions to the special issue suggest, first, that REDD+ design in the studied countries has generally lacked social legitimacy and sidelined key actors who can considerably influence land-use sector dynamics. Second, they show that REDD+ early actions have tended to oversimplify local realities and have been misaligned and local needs. Third, REDD+ efforts have remained constrained to the forestry or climate mitigation policy sectors and have thus suffered from a lack of policy harmonization. As REDD+ moves from its preparedness to its implementation phase, more research efforts should be aimed at analysing the power relations that underpin and determine the design and implementation of REDD+ policies and actions, the potential for and limits to the vertical and horizontal coordination of land-use policies and management, and the processes of resistance to or accommodation of REDD+ practices on the ground. In doing so, we advocate for multi- and transdisciplinary research that does not take for granted the benefits of REDD+ and which critically scrutinizes the multiple goals of this ambitious international policy framework, and where it sits within the broader Paris Agreement implementation agenda.
\end{abstract}

Keywords: REDD+; environmental governance; politics; conflict; climate change

\section{Introduction}

Reducing Emissions from Deforestation and Forest Degradation, conserving and enhancing forest carbon stocks, and sustainably managing forests (REDD+), has become a reference framework for national forest governance across many tropical and subtropical forest countries [1,2] These countries have used funds from multilateral and bilateral aid platforms to re-organise forest management and conservation policy around the idea of mitigating climate change, including the development of national REDD+ strategies and both carbon accounting and benefit-sharing protocols [3]. In parallel, international conservation organizations have mobilised REDD+ principles and assumptions to promote small-scale pilot activities across the tropics, in order to capture the economic value of any resulting land-use emission reductions, mostly and rather limitedly through voluntary carbon markets [4].

REDD+ emerged at a time when an alternative path to the arguably dead-end of the Kyoto Protocol needed to be carved out that would allow all countries to participate in long-term cooperative action. The prospect of avoided deforestation being a cheap mitigation option [5] convinced many countries to endorse the adoption of the REDD+ mechanism as part of the 2007 Bali Action Plan that contained the building blocks of what has ultimately become the 2015 Paris Agreement. Thus, the idea of payment for standing forests was born and is now a core element of many forest nations 
in their Nationally Determined Contributions (NDCs) under the Paris Agreement [6]. International programmes, in particular the World Bank's Forest Carbon Partnership Facility (FCPF) and UN-REDD, have been instrumental in paving the way for host country capacity building and readiness activities to enable implementation on the ground [7].

The political traction that REDD+ has sparked in the international climate change negotiations and multilateral funding frameworks has translated into considerable academic attention. A search in Scopus, an international repository of scientific articles, reveals that the number of articles with "REDD" in the title alone has exponentially increased from two articles in 2007 to over 550 articles in 2017. The search ignores of course the articles that might have studied REDD+ policy and projects using other terminology, which implies that REDD+ analyses are probably more numerous. Generally speaking, research on REDD+ can be classified across two very broad schools of thought. On the one hand, there are those who have looked skeptically at the framework, departing from the premise that REDD+ might be, or might become, yet another top-down, blueprint approach to environmental management that might reify inequities in access to forest and land resources while limiting the "right to develop" of host countries (e.g., [8,9]). On the other hand, there are those who have approached REDD+ more optimistically, looking at how the framework could support both conservation and development aspirations through better design and implementation [10,11].

It is commonly agreed across these two schools that REDD+ policy preparedness and pilot project implementation have been characterized by numerous challenges, some related to broader UNFCCC and aid policy features and others related to in-country lack of capacities, policy misalignments and an unfavourable political economy $[12,13]$. There is also consensus that REDD+ programs and actions can fall short in terms of their legitimacy [14,15], as well as result in social conflicts, unexpected and counterproductive tenure arrangements [16] or limited wellbeing gains [17,18]. However, it is also true that the short shelf life of REDD+, coupled with the fact that forest and land-use governance reform require long-term thinking and a profound change in national and international political economies [19], increases the risk that both scholars and the international policy community might throw "the baby out with the bathwater".

This special issue is an attempt to contribute to this burgeoning research on REDD+, providing theoretically grounded and empirical evidence on three analytical domains: the politics of REDD+ design; the lessons from REDD+ early actions; and REDD+ policy interplays. The contributions are a response to a question that the two guest editors considered timely to pose in 2015, i.e., how is REDD+ unfolding and with which consequences? With many countries developing their national REDD+ strategies or hosting pilot projects over the last few years, it was important to ask about the political nature of these endeavours and to gather specific evidence on how various governments have designed and rolled out their REDD+ strategies, and how and why a range of public and private actors have or have not become involved in such processes. It was important to explore which rationales, techniques, views and values are being contested and constructed in the design of REDD+ national strategies and pilot projects, which conflicts have emerged and why, or how coordination across competing actors and interests has been pursued. Relatedly, it was timely to look for more evidence on the impacts of policies and projects on specific environments, peoples, and ecosystems, since in some cases these interventions might have been in place for a few years by then. Finally, if one assumed that reducing deforestation and improving forest governance required harmonizing land-use policies and eliminating both public and private incentives that result in the unsustainable management of forests, then it was necessary to collect evidence on the ability of REDD+ processes to improve forest policy regulations and influence both development and land-use policies.

The contributions below shed light on the above-mentioned issues, and we think that, combined with other emerging evidence, they provide a solid knowledge basis upon which to build the research agenda of REDD+ in its post-preparedness phase. As developing countries move toward and into implementation of their national REDD+ strategies, in the broader context of their NDCs, some of the "red flags" identified to date in terms of REDD+ policy design and on-the-ground implementation 
will require further attention as new questions will also become relevant. In the closing of this article, we highlight what we think these questions might be and in doing, so we hope to be drawing a sensible agenda for the near future.

\section{Politics of REDD+ Design}

The collection starts with a batch of eight articles that analyse the politics of REDD+ design, as well as of related funding frameworks. The fact that this is the topic of the special issue deserving more coverage can be explained by the fact that REDD+ in its early years mostly consisted of developing national policy strategies and supporting pilot, often short-lived projects, while the translation of these policy processes and the impacts of pilot projects are yet to be seen or realized. An underlying concern across these contributions relates to the lack of legitimacy that these processes and projects have suffered from, and the problematic absence of social actors that play a key role in development planning and land-use change.

The first contribution explores the role that NGOs have played in crafting and facilitating Norway's International Climate and Forest Initiative (NICFI), the world's largest single country attempt to support the development of climate and REDD+ related policies and projects over the last decade in developing countries. Hermansen et al. [1] use qualitative process-tracing to analyse how NGOs in Norway, Brazil, Indonesia, and Tanzania have cooperated with the Norwegian and their own country governments to facilitate the early start of REDD+ policy design and implementation. The authors argue that cooperation should be distinguished from co-optation to the extent that NGOs remain critical of certain aspects of REDD+ and have found forums and ways to exert an influence on and to change NICFI's operating procedures. In Norway, NGOs have opted to use private forums to voice their concerns directly to government and have remained strategically quiet in the public arena about the challenges of REDD+ implementation "on the ground", albeit with some exceptions from development-focused NGOs. The authors show that public criticism of REDD+ by NGOs has been minimal in Brazil and Tanzania where NGOs have been mostly cooperative, driven by the fact that they became core recipients of aid and thus key implementation actors.

The articles by Špirić et al. [15] and Airey and Krause [20] explore the process of REDD+ policy design in Mexico and Guyana, respectively. In these two Latin American countries, the authors observe a lack of inclusion and recognition of key actors in the policy process, although their analytical and scalar focus is different. Spiric and colleagues explore the legitimacy of the political processes leading to Mexico's REDD+ national strategy over the period 2011-2014, grounded in stakeholder and discourse analysis. The authors highlight that the government agencies have retained most decision-making power, while representatives of relevant land-use sectors and local communities have been absent from formal decision-making forums. They also show the existence of three main narratives about REDD+ in Mexico and demonstrate that the narrative predominantly held by government agencies, multilateral and international conservation organizations has found its way into the strategy's final draft much more than other narratives supported by NGOs and academia. Therefore, Spiric and colleagues argue that Mexico's REDD+ process should “become more inclusive, decentralised, and better coordinated to allow for the deliberation and institutionalisation of different actors' ideas in REDD+ design" (ibid.).

Airey and Krause, in turn, use in-depth interviews with the Amerindian community of Chenapou to analyse the extent to which they had been informed about and participated in the design of Norway-funded Guyana's Low Carbon Development Strategy (LCDS), in which any ensuing REDD+ policy and project developments should be grounded. Their analysis suggests that the government has neither dedicated sufficient resources nor used appropriate participatory tools to inform and involve the people of Chenapou in the design of the LCDS. Additionally, no attempt was made to address the fact that Amerindian communities are not properly represented in the country's political system, with their traditional village council institutions disconnected from the state administration and thus from decision-making powers. For the authors, this is problematic on political and ethical grounds, but also conducive to risks in future REDD+ implementation. In their own words, "by not engaging 
with the community, the actors in power (i.e., the governments of Guyana and Norway) miss out on the value of local knowledge and input, which may hold significant benefit for projects" (ibid.).

Another two articles dig deeper into issues related to participation and representation in South-East Asia. Huynh and Keenan [21] explore how Vietnamese policy actors view REDD+ policy development and their influence on these processes. In line with Spiric et al., the authors examine the influence of state and non-state actors on the 2012 National REDD+ Action Program (NRAP) processes, using a combination of document analysis and semi-structured interviews. They find that most non-state actors in REDD+ exerted a minor influence on NRAP developments, and demonstrate that national NGOs were much more entangled and thus satisfied with the state's rather authoritarian decision-making procedures than international NGOs, which felt more excluded and less able to influence the policy process. For the authors, in the coming years, non-state actors will be able to take advantage of the fact that the country's ruling party is increasingly eager to receive information on best REDD+ practice and, in this context, they should find "the right tactics" to improve the participatory character of REDD+ policy and "to expand and build extra-sectoral partnerships across multiple organisational boundaries, including those beyond the forestry sector" (ibid.).

In Lao PDR, Mustalahti et al. [22] analyse the importance and involvement of civil society organisations (CSOs) in the design and implementation of REDD+ and the European Union Action Plan on Forest Law Enforcement, Governance and Trade (FLEGT), since these are two related policy frameworks that aim to address deforestation, forest degradation and promote sustainable forest management. Informed by both surveys and interviews, the authors show that CSOs have been key players in the roll-out of both frameworks to date, but they argue that such involvement has not resulted in significant changes in the government's objectives and decisions over both frameworks. In line with Huynh and Keenan above, Mustalahti et al. distinguish between international and national CSOs but suggest that, while both experience powerlessness in front of the state, the latter are further hampered by their lack of knowledge, capacities and resources to follow-up, participate and possibly benefit from the two policy processes. Furthermore, the authors point out that CSOs should better coordinate among themselves, since doing so might increase their technical capacity and maximize the resources available to mobilize other CSOs working in environment and development issues more broadly, which could ultimately increase their decision-making power over REDD+ and FLEGT policy processes.

The first batch of articles focused on the politics of REDD+ design ends with another empirically grounded article exploring REDD+ policy in two African countries, and with a contingent valuation study of REDD+ costs and a theoretically informed review of REDD+ research through a justice lens. Asiyanbi et al. [23] investigate the early development of REDD+ in Ghana and Nigeria and they distinguish between the processes and principles that have guided the writing of REDD+ national strategies from the early steps conducted to roll-out the strategies, namely, institutional and capacity building, carbon accounting and property rights over land and carbon. Regarding the former, and in contrast with other contributions in the collection, they show that policy design included the diversity of all relevant actors through multiple meetings and forums over time, and captured their contrasting interests through broad, ambitious and possibly contradictory aims and objectives in policy documents. Regarding the latter, they demonstrate that in both countries, there have been intra-governmental struggles over who should gain institutional control of the REDD+ process, and favoritism over which social actors should be involved and benefit from capacity building. Simultaneously, state administrations have used REDD+ to assert control over land, forest and carbon at the expense of community rights and public access to timber and non-timber forest products.

Thompson et al. [24] investigate farmers' Willingness To Accept (WTA) compensation for REDD+ in southern Cameroon. Their analysis allows understanding the costs or foregone benefits that farmers face when engaging in REDD+ activities and the appeal of such activities when they land in complex social-ecological landscapes characterized by land-use change and social heterogeneity. The study demonstrates that farmers' WTA is much higher than the previously calculated opportunity costs for 
conserving forests in Cameroon and elsewhere, and they also show that such WTA varies according to expectations over agricultural markets and tenure security, as well as according to farmers' age and household land-use patterns. The findings challenge the assumption that REDD+ is a cheap mitigation option and they shed light on the importance of delivering conservation incentives paying attention to the diversity of farming strategies and livelihood needs. Finally, Marion Suiseeya's [25] offers a comprehensive review of justice-related REDD+ debates and demonstrates how these have been generally grounded in simplistic visions of either distributive or procedural justice, ignoring the importance of recognition as the third pillar of justice. According to her, embracing the recognition principle would make of REDD+ a less technocratic endeavour, more sensitive to the "values, identities, lifeways, and voices" that might be displaced as a result of REDD+ activities.

\section{Lessons from REDD+ Early Actions}

When it comes to understanding the early lessons of REDD+ early actions, there are several themes that the six articles below point to repeatedly. They include the peril of oversimplification and generalisation at the local level, thereby missing local dynamics and complexities and leading to adverse outcomes; the peril of not aligning project goals with local needs; the relatively low levels of deforestation in the poorest segments of society; and the potential of conflict if tenure rights are unclear or ignored.

To begin, Gebara and Agrawal [26], apply Foucault's concepts of governmentality and technologies of governance to argue that local complexities, heterogeneities and multi-dimensional capacities are often forsaken for linear and rational simplicity. Their case study focuses on reactions to rewards and punishments by smallholder farmers in Brazil. They find that the techniques of remuneration and coercion on which a rewards and punishments approach rests are only supporting limited behavioural changes on the ground, achieving negative adaptations and deforestation practices, reducing positive feedbacks and, above all, only producing short-term outcomes at the expense of positive long-term land use changes. They conclude by emphasising "the importance of looking at local heterogeneities and capacities and the need to promote trust, altruism and responsibility towards others and future generations" (ibid.) as one key lesson from REDD+ early actions. Conceptually, the authors contribute to the governmentality literature by adding to its focus on rationalities of governance a regard for social practices within which such rationalities are embedded.

Next, Trædal et al. [27] apply a livelihoods framework to discuss the link between livelihoods and land use amongst smallholder farmers. Their findings, based on work in Vietnam, similarly indicate that one-dimensional perspectives of the drivers behind deforestation do not lead to appropriate solutions to address the underlying dynamics at stake. Instead, the authors suggest addressing issues of land tenure and the scarcity of productive lands, and generating viable off-farm income alternatives through engaging with multiple stakeholders, which could include business-oriented households in control of a commodity trade (coffee in this case) and of land transactions. Another finding of this study is that the poorest segments of the population are found to deforest the least. Their data showed that middle to better-off households cultivate most land (including for coffee production) and have cleared more forest land for agriculture over the years than poorer households. This is true especially when taking into account uncertified, or illegal, clearing. The authors therefore conclude that the focus on the linkages between poverty and coffee-related forest encroachment seems to be overemphasised in PES and REDD+ policies and discourses. Their main argument is therefore "that, in order to enable a more comprehensive understanding of land-use change and its management, the focus should be expanded beyond the poverty-environment nexus" (ibid.).

Cadman et al. [28] use an online survey and two workshops targeting a number of REDD+ stakeholder groups to investigate the quality of REDD+ governance in Nepal and Papua New Guinea (PNG), in order to infer lessons on the framework's legitimacy and to identify what matters most for its future effectiveness, given distinct national priorities and contexts. The authors demonstrate that the governance principles of inclusiveness, resources, accountability, and transparency are ranked 
very highly by most participants in both countries, even if they are distinctively prioritised in different ways, while the principles of agreement, dispute settlement, and problem solving were the least prioritised and again in different orders. A key finding of the article is not so much the existence of certain 'consensus' on which principles should matter most in designing and implementing REDD+, but the fact that in both countries the lack of resources and inclusiveness are two related and important caveats of REDD+ implementation, which taken together compromise the transparency and accountability of REDD+ governance. In other words, a limited participation of key stakeholders given the lack of funding to facilitate such participation might lead to unfair decisions and suspicion over who made such decisions and why. For the authors, their findings also challenge the idea that REDD+ governance will be on safe grounds if focused narrowly on FPIC or safeguards, rather than on broader governance principles that merit attention across potentially diverging socio-political and cultural contexts.

Next, Holmes et al. [29] also find that success of REDD+ requires more nuance and alignment with local needs. The authors used semi-structured interviews and participatory methods over the span of 11 years in an Embera community in Panama to examine how local communities sought to reduce emissions from deforestation and benefit from carbon offset trading while improving local livelihoods. Their findings lead the authors to suggest the development of a support system for implementation through bridging institutions and the use of REDD+ for conflict resolution around tenure issues, in addition to economic incentives, as ways to respond to the needs of local communities and improve their livelihoods. In conclusion, they propose that successful implementation of REDD+ projects in small rural or indigenous communities requires "a shift in paradigm, away from 'evidence-based payments' and towards an integrated development approach" (ibid.). This sums up a key lesson derived from this work: REDD+ takes much longer to be implemented because it requires redefining livelihood strategies, i.e., transformative change, and this cannot simply be achieved through evidence-based payments based on the current market price for carbon. Rather, evidence-based payments need to be combined with development and poverty reduction.

This issue of conflict resolution is also picked up by Work [30]. Taking a landscape approach to analysing forest-based climate change mitigation policies and land grabs in Cambodia, Work argues that forest-based climate change mitigation policies can reduce conflict through attention to tenure rights, responsibilities and authority of citizens, and by improving project landscapes. However, given the need for resource capture to generate economic growth, conflict is intrinsic to climate change policies. This exposes, according to the author, "deep contradictions at the heart of climate change policies" that require attention if "nothing but forest islands" and "castaway communities" are to be avoided (ibid.).

Finally, Pfaff et al. [31], in a study on shifts in impacts of Protected Areas (PAs) in Mexico over time, comparing the 1990s with the period 2000-2005 when conservation politics had allegedly shifted, find that PAs have indeed shifted in impacts from being 'paper parks' to achieving a reduction of $3.2 \%$ in loss on average. The authors also find that PAs in the case of Mexico do slightly better in conservation of forests, and that the strictness and proximity to cities have a positive impact on their success. With this research, they contribute to understanding variation in forest impacts over time, which is much less understood compared to impacts across space.

\section{REDD+ Interplays}

The special issue now turns to five articles that shed light on the extent to which REDD+ policy or early actions have been able to influence other policy frameworks that might contradict REDD+ objectives, or to what extent REDD+ can be an opportunity to coordinate different policy sectors. The contributions suggest overall the existence of tension between what has been subsumed under REDD+ as additional to deforestation, namely forest degradation, sustainable forest management, conservation and enhancement of forest carbon stock, as well as non-carbon benefits and safeguards, and what significantly impacts deforestation rates but remains outside 
of the scope of the REDD+ mechanism. Additionally, as also highlighted by the first batch of articles, the contributions demonstrate that the agricultural and extractive industries have been problematically sidelined, purposely or not, from REDD+ policy discussions and policy harmonization efforts, which have remained constrained to the forestry or climate mitigation policy sectors. Equally, it is shown that REDD+ governance is characterised by a lack of integration of local, national and international concerns.

Fujisaki et al. [32], based on a comparative study of five countries, conclude that, despite structural differences across countries, REDD+ can potentially encourage new forms of environmental governance that promote a cross-sectoralism and stakeholder participation. However, their research identifies a lack of operationalisation of cohesiveness and inclusiveness in environmental policymaking processes in most developing countries, including in REDD+. They argue that cohesiveness within a broader governance system is key to defining the capacity of REDD+ governance, i.e., harmonising different policy sectors and interests that have impacts on forests. Furthermore, they highlight the need for inclusiveness and policy support for those affected by REDD+ to ensure their voices are heard in decision-making processes to overcome structural inequalities. In examining whether emerging governance arrangements help REDD+ development by delivering participatory mechanisms for policy coordination, they find that REDD+ potentially encourages a new form of environmental governance that promotes a cross-sectoral approach and stakeholder participation.

Blum and Reinecke [33] draw on social roles to examine eight different REDD+ governance processes in terms of the variety of practical authoritative roles enacted in administration, finance, decision making and knowledge production. By systematically identifying the ways in which different roles are filled, the authors develop a typology of structural role practices and underlying rationales. This can help assess legitimacy and empirically operationalise REDD+ governance performance. Their study illustrates that if new governance practices are created, the actors involved often bring in their understandings about roles (including working culture, values and administrative routines), which may not correspond with what was envisioned in the first place. Therefore, to avoid conflict during later phases, and for more clarity, expectations and conceptualizations of roles need to be discussed in the initial phase.

McElwee et al. [34] examine if REDD+ policies and projects on the ground acknowledge that climate change is likely to impact forests and forest users, if this knowledge is built into REDD+ policy and activities, how households in forested areas subjected to REDD+ policy are vulnerable to climate change, and how REDD+ can help or hinder adaptation to climatic changes. Using stakeholder interviews, focus groups and household surveys in three provinces in Vietnam, the authors find a lack of coordination between mitigation and adaptation policy with regard to REDD+ at the sub-national level. Policies for forest-based mitigation at national, subnational and project levels have paid little attention to the adaptation needs of local communities, where climate changes are already being experienced. They also suggest that there is an untapped potential for understanding how REDD+ activities could facilitate increased resilience. Most studied projects and policies did not explicitly target their activities to focus on adaptation or resilience, and in one case at least, negative livelihood impacts increased household vulnerability to climate change. Key barriers to integration include sectoral specialisation, a lack of attention in REDD+ projects to livelihoods and inadequate support for ecosystem-based adaptation.

In discussing the perils and merits of REDD+, or the question of whether REDD+ invites a skeptical or an optimistic outlook, Mulyani and Jepson [35] find that in the case of Indonesia REDD+ and institutional interplay have led to notable transformations in its forest institutions. Based on 'path dependence' theory and eighty semi-structured interviews with REDD+ policy actors, the authors seek to determine the extent to which the REDD+ initiative has created a critical juncture for institutional change, the authors examine Indonesia's 'one map initiative' as the government's response to a call for greater transparency in implementing REDD+ and find that it has indeed led to improved transparency, public participation and coordination among ministries. It has shown an ability to break the old 
path-dependence of map making but the research also uncovered several historical events that preceded the REDD+ initiative as contributing factors to the relative success of REDD+ in effecting forest governance reform.

Finally, Pelletier et al. [36] examine the interplay between REDD+ and community forest management (CFM) to determine the latter's potential role of in achieving forest carbon benefits and social co-benefits for forest communities. Their systematic review of CFM case studies uncovers that there is strong evidence of CFM's role in reducing degradation and stabilising forested landscapes. However, the review also shows less evidence about its role in reducing deforestation. For social benefits, they find that CFM contributes to livelihoods, but its effect on poverty reduction may be limited. This might be because CFM may not deal adequately with the distribution of benefits within communities or user groups. The authors, like others in this special issue, argue that the recognition of rights for forest communities is one first step in promoting CFP-based REDD+ interventions and achieving both, positive biophysical and positive social outcomes.

\section{Conclusions: A Renewed Research Agenda for REDD+}

Back in 2011, we sketched out a research agenda for REDD+ which was built around three pillars: (i) the politics of REDD+ national strategy design, specifically "how governments are designing REDD+ strategies, what degree of coordination and reform across policies and sectors is being sought and achieved and how different government and non-governmental actors are being involved in such discussions, and why" [37]; (ii) the interplay between REDD+ and other policies and market processes in the land-use sector, and in particular "whether REDD+ is able to transcend forest sector regulations, based on cross-sectoral and coordinated policy bodies and, ... , how REDD+ policies and actions unfold in local contexts, through existing commercial networks, extension services and both legal and illegal markets for natural resources" (ibid.); and (iii) the impacts of REDD+ policies and measures, including how these might transform institutions and livelihoods related to forest conservation and land-use, and how resource and carbon monitoring systems might change such institutions and be harmonized across scales.

This research agenda has been thoroughly pursued over the last few years, as demonstrated by the articles in this special issue and others beforehand (e.g., [38]). The contributions to this special issue generally demonstrate that the development of REDD+ national strategies have been characterized by participation deficits and coordination challenges, including the reproduction of illegitimate forms of top-down decision making, or the lack of coordination across land-use related policy sectors, which can ultimately undermine the legitimacy and effectiveness of REDD+, now and in the future. However, the development of REDD+ strategies has contributed in some countries to open up policy-making processes, and has improved land-use and forest governance, for example by unearthing and subsequently resolving existing conflicts over forest access and resource use. In turn, research focusing on the role that specific land-use lobbies have played in influencing the contents of national REDD+ strategies or in jeopardizing policy coordination processes remains rare. In other words, detailed analyses of the power relations underpinning REDD+ decision-making and implementation are lacking.

Nuanced understandings of how forest and rural communities have responded to or become engaged in REDD+ pilot projects have been published more recently [39-41] and, as REDD+ moves from the preparedness to its early implementation phase-with some countries signing Emission Reduction Purchase Agreements (ERPAs) and delivering quantifiable carbon emission reductions in forthcoming years-, we think that research on REDD+ implementation is likely to flourish. In-depth analyses of social-ecological impacts will thus be required, ideally combining distinct forms of expertise to address the multiple dimensions of REDD+, i.e., from spatial assessments to measure its environmental effectiveness to ethnographic accounts of local institutional and cultural change [42,43]. In line with others [44], we advocate for multi- or transdisciplinary research that takes into account the complexity of the social-ecological systems within which REDD+ actions will unfold, as well as 
the latter's (often problematic) rationale and multiple goals. Future research should be aware that many of those who have a stake in land-use management and forest conservation-including 'the rural poor'-might not perceive reducing or stabilizing emissions in the land-use sector through external incentives as "the right thing to do", and research should acknowledge that such efforts might in many contexts be people's last concern. Embracing such premises can allow researchers and practitioners to be more sensitive to local people's needs, interests and concerns regarding REDD+, as well as to become more aware of whose REDD+ it is, and why.

To conclude, and if we ask ourselves the question that underpins this special issue, it is not surprising that we are not able to provide a definite answer. In spite of being set as an international policy framework with well-established procedures and development phases, the special issue contributions show that REDD+ is unfolding differently in host countries, depending on state governance structures, cultural practices, and understandings of who should be ultimately responsible for operationalizing and realizing REDD+ across policy and implementation scales. In all countries, of course, the political economy of land-use and changing market dynamics will be critical in determining the viability and success of REDD+ activities on the ground. We cannot provide a definitive answer either as regards the consequences of REDD+. The special issue contributions, however, suggest that REDD+ runs the risk of replicating the mistakes of other policy approaches to environmental management, such as protected areas, integrated conservation and development projects and more recently payments for ecosystem services. These include the prioritization of technical and environmental goals over social justice considerations, the disconnect of project rationales and activities from local realities, and the insufficient attention to the actual drivers of environmental change and biodiversity loss. We are indeed at a crossroads now between relegating REDD+ to a similar fate as many previous forest conservation attempts on one side and forging ahead with much stronger attention paid to local needs, dynamics and complexities and the actual drivers of deforestation on the other.

Acknowledgments: Esteve Corbera acknowledges the financial support of the UAB-Banco de Santander Talent Retention programme and notes that this work contributes to ICTA-UAB "María de Maeztu Unit of Excellence" (MDM-2015-0552).

Conflicts of Interest: The authors declare no conflict of interest.

\section{References}

1. Hermansen, E.A.T.; McNeill, D.; Kasa, S.; Rajão, R. Co-Operation or Co-Optation? NGOs' Roles in Norway's International Climate and Forest Initiative. Forests 2017, 8. [CrossRef]

2. Vijge, M.J.; Brockhaus, M.; di Gregorio, M.; Muharrom, E. Framing National REDD+ Benefits, Monitoring, Governance and Finance: A Comparative Analysis of Seven Countries. Glob. Environ. Chang. 2016, 39, 57-68. [CrossRef]

3. Dunlop, T.; Corbera, E. Incentivizing REDD+: How Developing Countries Are Laying the Groundwork for Benefit-Sharing. Environ. Sci. Policy 2016, 63, 44-54. [CrossRef]

4. Sunderlin, W.D.; Sills, E.O.; Duchelle, A.E.; Ekaputri, A.D.; Kweka, D.; Toniolo, M.A.; Ball, S.; Doggart, N.; Pratama, C.D.; Padilla, J.T.; et al. REDD+ at a Critical Juncture: Assessing the Limits of Polycentric Governance for Achieving Climate Change Mitigation. Int. For. Rev. 2015, 17, 400-413. [CrossRef]

5. Stern, H.N.; Britain, G. The Economics of Climate Change: The Stern Review; Cambridge University Press: Cambridge, UK, 2007.

6. Savaresi, A. A Glimpse into the Future of the Climate Regime: Lessons from the REDD+ Architecture. Rev. Eur. Comp. Int. Environ. Law 2016, 25, 186-196. [CrossRef]

7. Angelsen, A.; Brockhaus, M.; Sunderlin, W.D.; Verchot, L.V. Analysing REDD+: Challenges and Choices; Center for International Forestry Research (CIFOR): Bogor, Indonesia, 2012.

8. DeShazo, J.L.; Pandey, C.L.; Smith, Z.A. Why REDD Will Fail, 1st ed.; Routledge: New York, NY, USA, 2016.

9. Lund, J.F.; Sungusia, E.; Mabele, M.B.; Scheba, A. Promising Change, Delivering Continuity: REDD+ as Conservation Fad. World Dev. 2017, 89, 124-139. [CrossRef] 
10. Brown, M.I. Redeeming REDD: Policies, Incentives and Social Feasibility for Avoided Deforestation, 1st ed.; Routledge: New York, NY, USA; London, UK, 2013.

11. Turnhout, E.; Gupta, A.; Weatherley-Singh, J.; Vijge, M.J.; de Koning, J.; Visseren-Hamakers, I.J.; Herold, M.; Lederer, M. Envisioning REDD+ in a Post-Paris Era: Between Evolving Expectations and Current Practice. In Wiley Interdisciplinary Reviews: Climate Change; John Wiley \& Sons, Inc.: New York, NY, USA, 2017; Volume 8. [CrossRef]

12. Angelsen, A. REDD+ as Result-Based Aid: General Lessons and Bilateral Agreements of Norway. Rev. Dev. Econ. 2017, 21, 237-264. [CrossRef]

13. Burgess, N.D.; Bahane, B.; Clairs, T.; Danielsen, F.; Dalsgaard, S.; Funder, M.; Hagelberg, N.; Haule, C.; Kabalimu, K.; Kilahama, F.; et al. Getting Ready for REDD+ in Tanzania: A Case Study of Progress and Challenges. Oryx 2010, 44, 339-351. [CrossRef]

14. Glover, A.; Schroeder, H. Legitimacy in REDD+ Governance in Indonesia. Int. Environ. Agreem. Politics Law Econ. 2017, 17, 695-708. [CrossRef]

15. Špirić, J.; Corbera, E.; Reyes-García, V.; Porter-Bolland, L. A Dominant Voice amidst Not Enough People: Analysing the Legitimacy of Mexico's REDD+ Readiness Process. Forests 2016, 7. [CrossRef]

16. To, P.; Dressler, W.; Mahanty, S. REDD+ for Red Books? Negotiating Rights to Land and Livelihoods through Carbon Governance in the Central Highlands of Vietnam. Geoforum 2017, 81, 163-173. [CrossRef]

17. Shrestha, S.; Shrestha, U.B.; Bawa, K.S. Contribution of REDD+ Payments to the Economy of Rural Households in Nepal. Appl. Geogr. 2017, 88, 151-160. [CrossRef]

18. Vatn, A.; Kajembe, G.; Mosi, E.; Nantongo, M.; Silayo, D.S. What Does It Take to Institute REDD+? An Analysis of the Kilosa REDD+ Pilot, Tanzania. For. Policy Econ. 2017, 83, 1-9. [CrossRef]

19. Minang, P.A.; van Noordwijk, M. The Political Economy of Readiness for REDD+. Clim. Policy 2014, 14, 677-684. [CrossRef]

20. Airey, S.; Krause, T. Georgetown Ain't Got a Tree. We Got the Trees'-Amerindian Power \& Participation in Guyana's Low Carbon Development Strategy. Forests 2017, 8. [CrossRef]

21. Huynh, T.B.; Keenan, R.J. Revitalizing REDD+ Policy Processes in Vietnam: The Roles of State and Non-State Actors. Forests 2017, 8. [CrossRef]

22. Mustalahti, I.; Cramm, M.; Ramcilovic-Suominen, S.; Tegegne, Y.T. Resources and Rules of the Game: Participation of Civil Society in REDD+ and FLEGT-VPA Processes in Lao PDR. Forests 2017, 8. [CrossRef]

23. Asiyanbi, A.P.; Arhin, A.A.; Isyaku, U. REDD+ in West Africa: Politics of Design and Implementation in Ghana and Nigeria. Forests 2017, 8. [CrossRef]

24. Thompson, D.Y.; Swallow, B.M.; Luckert, M.K. Costs of Lost Opportunities: Applying Non-Market Valuation Techniques to Potential REDD+ Participants in Cameroon. Forests 2017, 8. [CrossRef]

25. Suiseeya, K.R.M. Transforming Justice in REDD+ through a Politics of Difference Approach. Forests 2016, 7. [CrossRef]

26. Gebara, M.F.; Agrawal, A. Beyond Rewards and Punishments in the Brazilian Amazon: Practical Implications of the REDD+ Discourse. Forests 2017, 8. [CrossRef]

27. Trædal, L.T.; Vedeld, P.O. Livelihoods and Land Uses in Environmental Policy Approaches: The Case of PES and REDD+ in the Lam Dong Province of Vietnam. Forests 2017, 8. [CrossRef]

28. Cadman, T.; Maraseni, T.; Breakey, H.; López-Casero, F.; Ma, H.O. Governance Values in the Climate Change Regime: Stakeholder Perceptions of REDD+ Legitimacy at the National Level. Forests 2016, 7. [CrossRef]

29. Holmes, I.; Potvin, C.; Coomes, O.T. Early REDD+ Implementation: The Journey of an Indigenous Community in Eastern Panama. Forests 2017, 8. [CrossRef]

30. Work, C. Forest Islands and Castaway Communities: REDD+ and Forest Restoration in Prey Lang Forest. Forests 2017, 8. [CrossRef]

31. Pfaff, A.; Santiago-Ávila, F.; Joppa, L. Evolving Protected-Area Impacts in Mexico: Political Shifts as Suggested by Impact Evaluations. Forests 2017, 8. [CrossRef]

32. Fujisaki, T.; Hyakumura, K.; Scheyvens, H.; Cadman, T. Does REDD+ Ensure Sectoral Coordination and Stakeholder Participation? A Comparative Analysis of REDD+ National Governance Structures in Countries of Asia-Pacific Region. Forests 2016, 7. [CrossRef]

33. Blum, M.; Reinecke, S. Towards a Role-Oriented Governance Approach: Insights from Eight Forest Climate Initiatives. Forests 2017, 8. [CrossRef] 
34. McElwee, P.; Nguyen, V.H.T.; Nguyen, D.V.; Tran, N.H.; Le, H.V.T.; Nghiem, T.P.; Vu, H.D.T. Using REDD+ Policy to Facilitate Climate Adaptation at the Local Level: Synergies and Challenges in Vietnam. Forests 2017, 8. [CrossRef]

35. Mulyani, M.; Jepson, P. Does the 'one Map Initiative' Represent a New Path for Forest Mapping in Indonesia? Assessing the Contribution of the REDD+ Initiative in Effecting Forest Governance Reform. Forests 2017, 8. [CrossRef]

36. Pelletier, J.; Gélinas, N.; Skutsch, M. The Place of Community Forest Management in the REDD+ Landscape. Forests 2016, 7, 170. [CrossRef]

37. Corbera, E.; Schroeder, H. Governing and Implementing REDD+. Environ. Sci. Policy 2011, 14, 89-99. [CrossRef]

38. Schroeder, H.; McDermott, C. Beyond carbon: Enabling justice and equity in REDD+ across levels of governance. Ecol. Soc. 2014, 19, 31. [CrossRef]

39. Corbera, E.; Martin, A.; Springate-Baginski, O.; Villaseñor, A. Sowing the Seeds of Sustainable Rural Livelihoods? An Assessment of Participatory Forest Management through REDD+ in Tanzania. Land Use Policy 2017. [CrossRef]

40. Nantongo, M.G. Legitimacy of Local REDD+ Processes. A Comparative Analysis of Pilot Projects in Brazil and Tanzania. Environ. Sci. Policy 2017, 78, 81-88. [CrossRef]

41. Poudyal, M.; Ramamonjisoa, B.S.; Hockley, N.; Rakotonarivo, O.S.; Gibbons, J.M.; Mandimbiniaina, R.; Rasoamanana, A.; Jones, J.P.G. Can REDD+ Social Safeguards Reach the 'right' People? Lessons from Madagascar. Glob. Environ. Chang. 2016, 37, 31-42. [CrossRef]

42. Bos, A.B.; Duchelle, A.E.; Angelsen, A.; Avitabile, V.; de Sy, V.; Herold, M.; Joseph, S.; de Sassi, C.; Sills, E.O.; Sunderlin, W.D.; et al. Comparing Methods for Assessing the Effectiveness of Subnational REDD+ Initiatives. Environ. Res. Lett. 2017, 12. [CrossRef]

43. Sunderlin, W.D.; de Sassi, C.; Ekaputri, A.D.; Light, M.; Pratama, C.D. REDD+ Contribution Towell-Being and Income Is Marginal: The Perspective of Local Stakeholders. Forests 2017, 8. [CrossRef]

44. Visseren-Hamakers, I.J.; Gupta, A.; Herold, M.; Peña-Claros, M.; Vijge, M.J. Will REDD+ Work? The Need for Interdisciplinary Research to Address Key Challenges. Curr. Opin. Environ. Sustain. 2012, 4, 590-596. [CrossRef]

(C) 2017 by the authors. Licensee MDPI, Basel, Switzerland. This article is an open access article distributed under the terms and conditions of the Creative Commons Attribution (CC BY) license (http://creativecommons.org/licenses/by/4.0/). 